\title{
Gene silencing of human RAMP2 mediated by short-interfering RNA
}

\author{
GIOVANNA ALBERTIN, MARISTELLA RUGGERO, DIEGO GUIDOLIN and GASTONE G. NUSSDORFER
}

\author{
Department of Human Anatomy and Physiology, Section of Anatomy, University of Padua, I-35121 Padua, Italy
}

Received March 20, 2006; Accepted May 22, 2006

\begin{abstract}
Adrenomedullin (AM) is a regulatory peptide widely expressed, along its receptors, in cells and tissues, of which it controls many basic and specific functions acting in an autocrine-paracrine manner. However, the unequivocal demonstration of the physiological relevance of the regulatory role of AM would require the study of cells where the endogenous AM system has been suppressed. For this task we developed a technique to silence the AM gene in human umbilical vein endothelial cells (HUVECs) and the human embryonal kidney cell line (HEK-293). AM acts via two subtypes of receptor, named AM1 and AM2, which derive from the interaction of the calcitonin receptor-like receptors with two chaperones, called receptor activity modifying proteins (RAMP2 and RAMP3). Hence, we developed a protocol to suppress the human AM1 receptor by silencing the RAMP2 gene by transfection with short interfering RNAs (siRNAs). HUVECs were transfected using a new Ambion transfection reagent. RAMP2 gene silencing was determined in HUVECs by measuring RAMP2 mRNA levels in transfected and control cells by realtime polymerase chain reaction. The RAMP2 gene silencing was $\sim 60 \%$ and was observed $48 \mathrm{~h}$ after transfection. Matrigel assay in vitro was carried out to evaluate the effects of siRNA sequences. HUVECs cells were plated on matrigel and the analysis of capillary-like tubule formation showed that the cells were viable. The knockdown of the RAMP2 gene decreased the formation of tubes in response to $10^{-8} \mathrm{M}$ AM. The conclusion is drawn that siRNA technology can be successfully used in the investigations on AM and AM receptor functions.
\end{abstract}

\section{Introduction}

Adrenomedullin (AM) is a multi-functional regulatory peptide, originally isolated from human pheochromocytomas (1),

Correspondence to: Dr Giovanna Albertin, Department of Human Anatomy and Physiology, Section of Anatomy, Via Gabelli 65, University of Padua, I-35121 Padua, Italy

E-mail: giovanna.albertin@unipd.it

Key words: short interfering RNA, gene silencing, real-time polymerase chain reaction, adrenomedullin, RAMP2, humans that exerts potent vasorelaxant and hypotensive effects (reviewed in refs. 2,3). AM acts via a calcitonin receptorlike receptor (CRLR), whose selectivity for AM depends on its interaction with a family of receptor activity modifying proteins (RAMPs): RAMP1 generates CGRP1 receptors, while RAMP2 and RAMP3 give rise to two selective AM receptors, provisionally named AM1 and AM2 (reviewed in refs. 4,5).

AM and AM-receptor genes are widely expressed in cells and tissues, of which AM controls specific and basic functions. The best recognized regulatory actions of AM include the inhibition of $\mathrm{Ca}^{2+}$-dependent agonist-stimulated aldosterone secretion from adrenocortical cells (reviewed in ref. 6) and the growth promoting effect on several normal and neoplastic cells (reviewed in refs. 3,7). Due to the rather low levels of circulating AM, it is commonly accepted that this peptide acts in an autocrine-paracrine manner $(3,6)$. However, the physiological relevance of the AM system-mediated functional cell control is far from being satisfactorily demonstrated.

To address this issue, several investigators tried to ascertain whether the suppression of the endogenous AM system alters the cell functions which are known to be regulated by AM. The suppression of the endogenous AM system was obtained by treating in vitro the cells with either selective antagonists of AM receptors, such as AM22-52 and CGRP8-37 (4), or antisense oligonucleotides directed against the AM gene (8). Using this approach, evidence has been provided that the endogenous AM system plays a relevant role in the regulation of i) the secretion and growth of human and rat adrenocortical cells (9-13); ii) the growth of human fibroblasts and keratinocytes (14); and iii) the proliferation of cord blood hematopoietic stem cells (15).

The recent introduction of short interfering RNA (siRNA) technology (16) has led to the development of powerful sequence-specific tools able to induce a long-lasting geneexpression suppression in mammalian cells. We have recently developed a procol to silence the AM gene in human umbilical vein endothelial cells (HUVECs) and human embryonal kidney cell line (HEK-293) (17), and here we describe the results of a study aimed to silence the RAMP2 gene in HUVECs by transfection with siRNAs. Gene silencing was evaluated by comparing the RAMP2 mRNA levels in siRNAtransfected and control cells, using real-time polymerase chain reaction (PCR) and by verifying whether transfected cells maintain their ability to arrange in capillary-like tubules in response to AM when cultured on Matrigel. 
Table I. siRNA sequence.

\begin{tabular}{|c|c|c|}
\hline Sequence range & & siRNA sequence \\
\hline \multirow[t]{2}{*}{ RAMP2-siRNA(1) 545-563 } & Sense & 5'-CCUCAUCACUCUUGUAGUA-3' \\
\hline & Antisense & 3'-GGAGUAGUGAGAACAUCAU-5' \\
\hline \multirow[t]{2}{*}{ RAMP2-siRNA(2) 290-308 } & Sense & 5'-UCAAAUGGAUCCUAUCGAA-3' \\
\hline & Antisense & 3'-AGUUUACCUAGGAUAGCUU-5' \\
\hline \multirow[t]{2}{*}{ RAMP2-siRNA(3) 358-376 } & Sense & 5'-GAGAUUGCCUGGAGCACUU-3' \\
\hline & Antisense & 3'-CUCUAACGGACCUCGUGAA-5' \\
\hline \multirow[t]{2}{*}{ RAMP2-siRNA(4) 417-435 } & Sense & 5'-GAGAGGAUCAUCUUUGAGA-3' \\
\hline & Antisense & 3'-CUCUCCUAGUAGAAACUCU-5' \\
\hline \multirow[t]{2}{*}{ RAMP2-siRNA(1) SCRAMBLE } & Sense & 5'-ACCAUGCCUUUAUUCGCUA-3' \\
\hline & Antisense & 3'-UAGCGAAUAAAGGCAUGGU-5' \\
\hline \multirow[t]{2}{*}{ RAMP2-siRNA(2) SCRAMBLE } & Sense & 5'-UAAAGUACGUUCUCGUGUA-3' \\
\hline & Antisense & 3'-UACACGAGAACGUACUUUA-5' \\
\hline
\end{tabular}

\section{Materials and methods}

Cells and reagents. HUVECs were obtained from Clonetics (Cambrex Bio Science, Milan, Italy). Endothelial cell growth medium (ECGM) was provided by PromoCell (PBI International, Milan, Italy), DNA oligonucleotide templates by MWG Biotech (Florence, Italy), Matrigel by Becton Dickinson Labware (Bedford, MA), and human AM peptide by Phoenix Pharmaceuticals (Belmont, CA). Fetal calf serum (FCS), 4',6diamino-2-phenylindole dilactate (DAPI), collagene, and all other chemicals and reagents were purchased from SigmaAldrich Corp. (St. Louis, MO).

siRNA preparation. Four siRNA for human RAMP2 were designed, chemically synthesized and purchased from Dharmacon (Lafayette, CO) in deprotected and desalted form. Two scramble sequences for RAMP2 were selected from two RAMP2-siRNA sequences. Sfold Web Server (http://sfold. wadsworth.org) was used to design specific scramble-siRNA (17). They were generated using the Silencer siRNA construction kit (Ambion, Austin, TX) (18). All sequences are shown in Table I. As a positive control Ambion's Silencer GAPDH-siRNA and scrambled sequences were used. Cy2labeled siRNA was synthesized using the Silencer siRNA labeling kit (Ambion), purified, resuspended and hybridized according to the manufacturer's protocol. The fluorescent siRNA was used to follow the transfection with fluorescence microscopy.

Cell culture. HUVECs were cultured in $0.1 \%$ collagen-coated flasks in ECGM, supplemented with 10\% FCS, 0.4\% ECGS/ heparin, $1 \mu \mathrm{g} / \mathrm{ml}$ hydrocortisone, $50 \mu \mathrm{g} / \mathrm{ml}$ gentamycin and $50 \mu \mathrm{g} / \mathrm{ml}$ amphotericin-B. For all experiments HUVECs were used at passages 4-6. Before transfection, the cells were trypsinized, and after trypsine inactivation, resuspended in normal growth medium and maintained at $37^{\circ} \mathrm{C}$ while the transfection complexes were prepared.
Transfection reagent and siRNA concentration. The duplexes, added in a single pool at a concentration of 10 or $50 \mathrm{nM}$, were used to transfect cells using the lipid-based agent for Reverse Transfection siPORT ${ }^{\mathrm{TM}} \mathrm{NeoFX}^{\mathrm{TM}}$ (Ambion). SiPORT NeoFX was diluted into serum-free medium. The siRNA sequences were diluted into serum-free medium to a final concentration of 10 or $50 \mathrm{nM}$, and then the diluted siPORT NeoFX and RNAs were combined. The formed transfection complexes were incubated for $10 \mathrm{~min}$ at room temperature and then dispensed into the empty wells of a culture plate. The cells were pipetted into the culture plate wells containing the transfection complexes. They were plated into 24- or 6-well plates at $2 \times 10^{4}$ or $15 \times 10^{4}$ cells/well, respectively.

Visualization of transfection. RAMP2-siRNA was chemically labeled using the Silencer Cy2 siRNA labeling kit (Ambion). Briefly, $5 \mu \mathrm{g}$ of RAMP2-siRNAs was labeled using $7 \mu \mathrm{l}$ of labeling reagent, and then purified and resuspended, as indicated by the manufacturer's protocol. The cells were transfected with $10 \mathrm{nM}$ Cy2-RAMP2-siRNA. After $20 \mathrm{~h}$ cells were fixed using methanol/acetic acid $(3: 1 \mathrm{v} / \mathrm{v})$ and examined under a fluorescence and a reverted phase-contrast light microscope.

HUVEC transfection with siRNAs. The cells were transfected into 6-well culture plates with 10 or $50 \mathrm{nM}$ of RAMP2-siRNA, GAPDH-siRNA and scrambled sequences. All quantities of siRNA tested were incubated in duplicate, and the experiments were replicated 3 times. The cells were incubated under their normal growth conditions and were monitored for gene silencing $48 \mathrm{~h}$ after transfection by real-time RT-PCR.

Total RNA extraction and RT. HUVECs were lysed directly in the culture wells, and total RNA extraction was performed with the SV total RNA isolation system (Promega Corporation, Madison, WI). RNA was eluted into RNase-free water, measured by spectrophotometry, and stored at $-80^{\circ} \mathrm{C}$ until use 
Table II. Primer sequence.

\begin{tabular}{|c|c|c|c|c|c|}
\hline Gene & Accession number & Temperature & & Oligo sequence & $\mathrm{nM}$ \\
\hline \multirow[t]{2}{*}{ RAMP2 } & NM_005854 & $60^{\circ} \mathrm{C}$ & Sense & 5'-CTGCTGGGCGCTGTCCTGAA-3' & 400 \\
\hline & & & Antisense & 5'-TTCTGACCCTGGTGTGCCTGTG-3' & 400 \\
\hline \multirow[t]{2}{*}{ GAPDH } & NM_002046 & $60^{\circ} \mathrm{C}$ & Sense & 5'-СТCTCTGCTCCTCCTGTTCGAC-3' & 400 \\
\hline & & & Antisense & 5'-TGAGCGATGTGGCTCGGCT-3' & 400 \\
\hline \multirow[t]{2}{*}{ HMBS } & NM_000190 & $60^{\circ} \mathrm{C}$ & Sense & 5'-GGCAATGCGGCTGCAA-3' & 400 \\
\hline & & & Antisense & 5'-GGGTACCCACGCGAATCAC-3' & 400 \\
\hline
\end{tabular}

(19). The RT of the total RNA was carried out as follows: oligo dT (Promega) and $1 \mu \mathrm{g}$ of target RNA were incubated at $70^{\circ} \mathrm{C}$ for $15 \mathrm{~min}$ and at $4^{\circ} \mathrm{C}$ for $5 \mathrm{~min}$, and then added to $20 \mu \mathrm{l}$ of a reaction mixture containing $0.5 \mathrm{mM}$ dNTPs (SigmaAldrich), $3 \mathrm{mM} \mathrm{MgCl}_{2}$, $1 \mathrm{U}$ ribonuclease inhibitor, ImProm-II reaction buffer and ImProm-II reverse transcriptase (Promega). The mixture was incubated at $25^{\circ} \mathrm{C}$ for $15 \mathrm{~min}$, at $42^{\circ} \mathrm{C}$ for $60 \mathrm{~min}$, and at $70^{\circ} \mathrm{C}$ for $15 \mathrm{~min}$ to inactivate reverse transcriptase.

Real-time PCR. Real-time PCR was carried out as previously described (20-22). Briefly, $1 \mu 1$ of the RT-reaction solution (diluted to $12 \mathrm{ng} / \mu \mathrm{l}$ ) and $12.5 \mu \mathrm{l}$ of IQ SYBR-Green Supermix (Bio-Rad Laboratories, Milan, Italy), containing $50 \mathrm{mM}$ $\mathrm{KCl}, 20 \mathrm{mM}$ Tris- $\mathrm{HCl}$ (pH 8.4), 3 mM MgCl $2,0.8$ mM dNTPs, SYBR-Green and 6.25 U iTaq DNA polymerase, were mixed to a final volume of $25 \mu \mathrm{l}$. PCR was performed in a Bio-Rad I-Cycler iQ detection system, using the following protocol: denaturation program $\left(95^{\circ} \mathrm{C}\right.$ for $\left.3 \mathrm{~min}\right), 35$ cycles of two steps of amplification $\left(95^{\circ} \mathrm{C}\right.$ for $15 \mathrm{sec}$ and annealing for $\left.30 \mathrm{sec}\right)$, and melting curve $\left(60-90^{\circ} \mathrm{C}\right.$ with a heating rate of $0.5^{\circ} \mathrm{C} /$ $10 \mathrm{sec})$. Primer sequences, annealing temperature and accession numbers are shown in Table II. During the exponential phase, the fluorescence signal threshold was calculated, and the fraction number of PCR cycles required to reach the threshold (cycle threshold, $\mathrm{Ct}$ ) was determined. $\mathrm{Ct}$ values decreased linearly with increasing input target quantity, and were used to calculate the relative mRNA expression, according to a mathematical quantification model (23). The specificity of amplification was tested at the end of each run by real-time PCR melting analysis, using the I-Cycler iQ software 3.0. All samples were amplified in duplicate and compared with the respective control. GAPDH or HMBS was used as a reference to normalize data.

Morphogenesis assay on matrigel. Unpolymerized Matrigel was placed in the well $\left(40 \mu \mathrm{l} /\right.$ well) of a 24 -well plate $\left(1.28 \mathrm{~cm}^{2} /\right.$ well) and allowed to polymerize for $1 \mathrm{~h}$ at $37^{\circ} \mathrm{C}$. Twentyfour hours from transfection with siRNA-RAMP2, HUVECs were trypsinized and $2 \times 10^{4}$ cells were plated in $500 \mu 1$ medium. Some wells were supplemented with $10^{-8}$ M AM. After $20 \mathrm{~h}$ of incubation in a $95 \%$ air - $5 \% \mathrm{CO}_{2}$ humidified atmosphere at $37^{\circ} \mathrm{C}$, the cells were fixed and their ability to give rise to a mesh of capillary-like tubules was assessed under a reverted phase-contrast light microscope, as detailed previously (24-26).

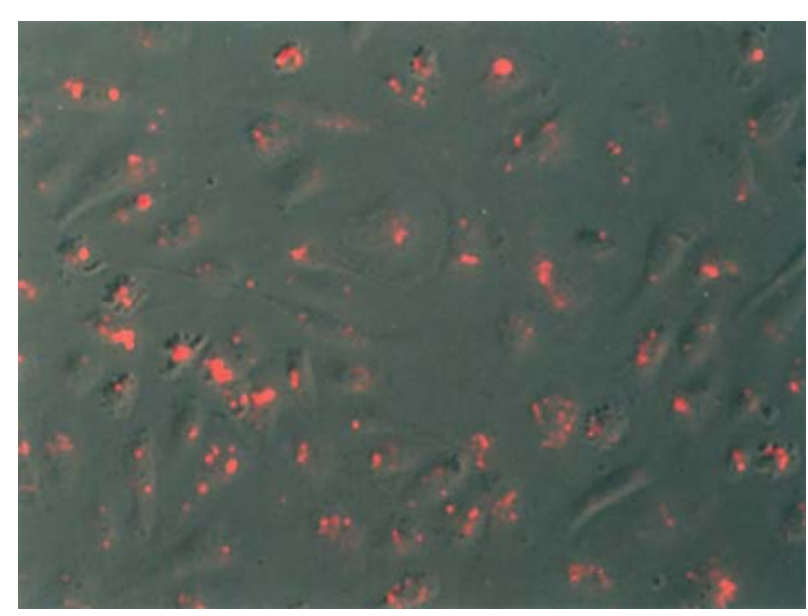

Figure 1. Visualization by fluorescence microscopy of Cy2-labeled RAMP2siRNAs transfected into HUVECs (red fluorescence spots) using the Ambion siPORT NeoFX.

\section{Results}

Using fluorescent RAMP2-siRNA, HUVEC transfection was monitored. Twenty hours after transfection, HUVECs exhibited red fluorescent spots in the cytoplasm near the nucleus (Fig. 1). Transfected cells were counted, and the efficiency of transfection was $80.7 \pm 4.1 \%$ (SD). HUVEC viability was assayed $24 \mathrm{~h}$ after transfection. Cells were trypsinized and counted in a Burker's camera: viability was $90 \%$ for control (cells incubated only with transfection reagent) and $85 \%$ for cells transfected with RAMP2-siRNA.

GAPDH and RAMP2-gene silencing in HUVECs was evaluated by real-time PCR $48 \mathrm{~h}$ after transfection with GAPDH-siRNA and RAMP2-siRNA. All siRNAs were tested at 10 and $50 \mathrm{nM}$ (Fig. 2). GAPDH-siRNA was used as a control to verify the capacity of cells to receive siRNA, and to analyze down-regulation of the target gene. The GAPDH gene was silenced by $\sim 40 \%$ with $10 \mathrm{nM}$ GAPDH-siRNA and there was no silencing with $50 \mathrm{nM}$ GAPDH-siRNA. RAMP2-siRNA induced a significant decrease in expression of RAMP2 mRNA compared to the controls. The gene was silenced by $\sim 60-65 \%$ with $10 \mathrm{nM}$ of RAMP2-siRNA, and by only $30 \%$ with $50 \mathrm{nM}$ of RAMP2-siRNA. Scrambled GAPDH- and RAMP2-siRNAs did not silence the respective genes. 


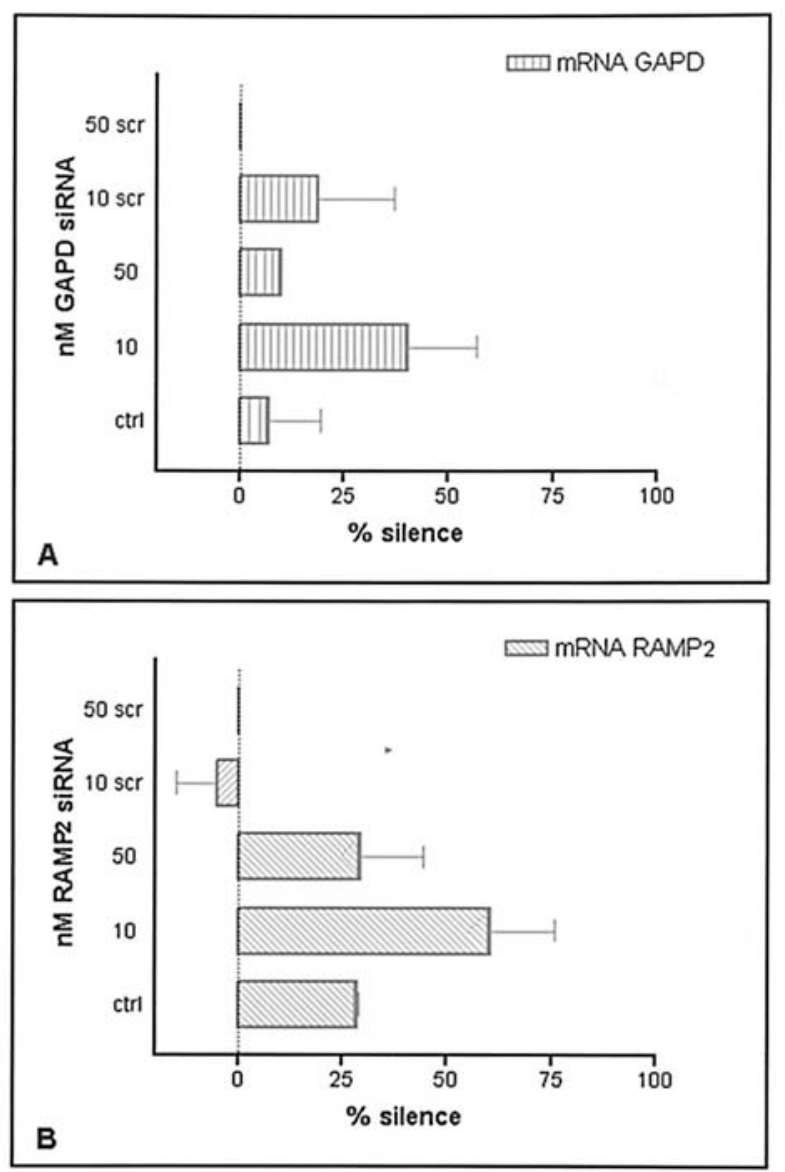

Figure 2. GAPDH- (A) and RAMP2-gene silencing (B) in HUVECs $48 \mathrm{~h}$ after transfection with different doses of specific siRNAs. Gene silencing is expressed as percent decrease of GAPDH and RAMP2 mRNAs in transfected cells as compared to the respective non-transfected controls. Bars are means \pm SD of three separate experiments.

After seeding on Matrigel, control HUVECs spread and alligned with each other to form branching anastomosing tubes with multi-centric junctions that within $20 \mathrm{~h}$ gave rise to a meshwork of capillary-like structures. AM $\left(10^{-8} \mathrm{M}\right)$ increased the length of the meshwork of the control, but not RAMP2siRNA-transfected HUVECs (Fig. 3).

\section{Discussion}

Gene silencing by siRNAs, although being a rather novel and rapidly evolving technology, is already regarded as a very promising technique, not only for mammalian functional genomics, but also for therapeutical purposes (16). To achieve good gene silencing, it is necessary to design specific RNA sequences with appropriate characteristics (27). Following these directions, we developed a protocol to silence the RAMP2 gene in HUVEC cells.

In the present study, we used a new transfection reagent, the Ambion reverse transfection siPORT NeoFX. Reverse transfection is an alternative method of transfection, where cells are transfected while still in suspension (i.e. after trypsinization and prior to plating). This method displays a minimal toxicity and has been reported to improve transfection efficiency over the standard pre-plated method for many cell types tested and saves an entire day in the process. Presumably,

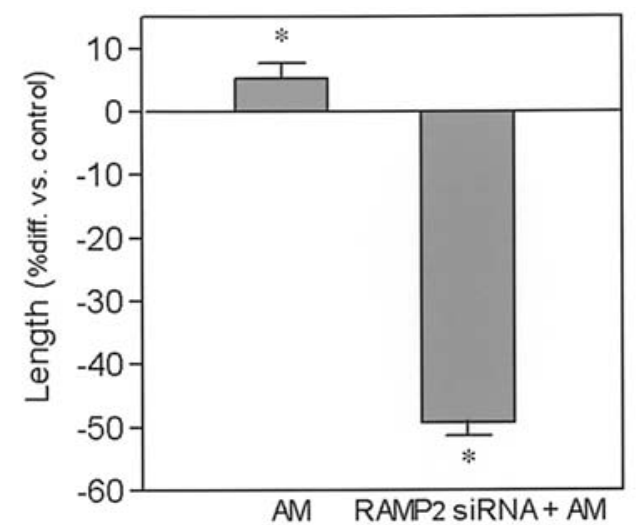

Figure 3. Effect of AM exposure on the length of capillary-like meshwork of control and RAMP2-siRNA transfected HUVECs cultured on Matrigel. Bars are means $\pm \mathrm{SD}$ of two separate experiments $\left({ }^{*} \mathrm{P}<0.05\right.$, Student's t-test $)$.

the amount of exposed cell surface, and not the number of transfection complexes, is the limiting factor in the traditional adherent transfection. Reverse transfection is believed to increase cell exposure to transfection complexes, thereby leading to a greater transfection efficiency.

Using this technique, we showed an optimal transfection efficiency, and real-time PCR demonstrated a knockdown of RAMP2 gene expression by $\sim 60-65 \%$. Of interest, we observed that transfection with too much siRNA did not evoke more knockdown: $10 \mathrm{nM}$ siRNA appears to be the best concentration. This observation is very important because transfection with high doses of siRNA has been reported to cause selected apoptosis and induction of stress-response genes in cultured cells (28). Moreover, evidence is available that low doses of siRNAs are not able to evoke a cytokine (interferon) response in mammalian cells (29), a finding of great relevance in light of the reported ability of inflammatory cytokines to induce AM-gene expression and AM release from different cell systems (30-34).

The AM receptor-mediated proangiogenic action of AM is well known and the sensitivity of in vitro Matrigel assay to test this effect of AM is well recognized (35-36). The good efficiency of our protocol for RAMP2 gene silencing and the ensuing impairment of AM1 receptor activity has been confirmed by the demonstration that control but not transfected HUVECs display a normal in vitro angiogenic response to AM.

Collectively, our present findings allow us to conclude that siRNA technology is a very promising tool for investigating the role of AM receptors in cell functional regulation.

\section{References}

1. Kitamura K, Kangawa K, Kawamoto M, Ichiki Y, Nakamura S, Matsuo $\mathrm{H}$ and Eto T: Adrenomedullin: a novel hypotensive peptide isolated from human pheochromocytoma. Biochem Biophys Res Commun 192: 553-560, 1993.

2. Hinson JP, Kapas S and Smith DM: Adrenomedullin, a multifunctional regulatory peptide. Endocr Rev 21: 138-167, 2000.

3. Lopez J and Martinez A: Cell and molecular biology of the multifunctional peptide adrenomedullin. Int Rev Cytol 221: 1-92, 2002.

4. Poyner DR, Sexton PM, Marshal I, Smith DM, Quirion R, Born W, Muff R, Fisher JA and Foord SM: International union of pharmacology. XXXII. The mammalian calcitonin generelated peptides, adrenomedullin, amylin and calcitonin receptors. Pharmacol Rev 54: 233-246, 2002. 
5. Hay DL, Howitt SG, Conner AC, Schindler M, Smith DM and Poyner DR: CL/RAMP2 and CL/RAMP3 produce pharmacologically distinct adrenomedullin receptors: a comparison of effect of adrenomedullin 22-52, CGRP8-37 and BIBN4096. Br J Pharmacol 140: 477-486, 2003.

6. Nussdorfer GG: Proadrenomedullin-derived peptides in the paracrine control of the hypothalamo-pituitary-adrenal axis. Int Rev Cytol 206: 249-284, 2001.

7. Belloni AS, Albertin G, Forneris ML and Nussdorfer GG: Proadrenomedullin-derived peptides as autocrine-paracrine regulators of cell growth. Histol Histopathol 16: 1263-1274, 2001.

8. Samson WK, Bode AM, Murphy TC and Resch ZT: Antisense oligonucleotide treatment reveals a physiologically relevant role for adrenomedullin gene products in sodium intake. Brain Res 818: 164-167, 1999.

9. Andreis PG, Albertin G, Conconi MT, Carraro G, Malendowicz LK, Ziolkowska A and Nussdorfer GG: Evidence for an autocrine-paracrine role of adrenomedullin in the cultured rat adrenal zona glomerulosa cells. Int J Mol Med 10: 401-405, 2002.

10. Rebuffat P, Forneris ML, Aragona F, Ziolkowska A, Malendowicz LK and Nussdorfer GG: Adrenomedullin and its receptors are expressed in the zona glomerulosa of human adrenal gland: evidence that ADM enhances proliferation and decreases apoptosis in cultured ZG cells. Int J Mol Med 9: 119-124, 2002 .

11. Malendowicz LK, Conconi MT, Parnigotto PP and Nussdorfer GG: Endogenous adrenomedullin system regulates the growth of rat adrenocortical cells cultured in vitro. Regul Pept 112: 27-31, 2003.

12. Rossi GP, Conconi MT, Malendowicz LK and Nussdorfer GG: Role of the endogenous adrenomedullin system in regulating secretion and growth of rat adrenal cortex. Hypertens Res 26 (Suppl): 585-592, 2003.

13. Ziolkowska A, Budzynska K, Trejter M, Tortorella C, Belloni AS and Malendowicz LK: Effects of adrenomedullin and its fragments 22-52 on basal and ACTH-stimulated secretion of cultured rat adrenocortical cells. Int J Mol Med 11: 613-615, 2003.

14. Albertin G, Carraro G, Parnigotto PP, Conconi MT, Ziolkowska A, Malendowicz LK and Nussdorfer GG: Human skin keratinocytes and fibroblasts express adrenomedullin and its receptors and adrenomedullin enhances their growth in vitro by stimulating proliferation and inhibiting apoptosis. Int J Mol Med 11: 635-639, 2003

15. Del Pup L, Belloni AS, Carraro G, De Angeli S, Parnigotto PP and Nussdorfer GG: Adrenomedullin is expressed in cord blood hematopoietic cells and stimulates their clonal growth. Int J Mol Med 11: 157-160, 2003.

16. Elbashir SM, Lendeckel W and Tuschl T: RNA interference is mediated by 21 - and 22-nucleotide RNAs. Genes Dev 15: 188-200, 2001.

17. Ui-Tei K, Naito Y, Takahashi F, Haraguchi T, Ohki-Hamazaki H, Juni A, Ueda R and Sago K: Guideline for the selection of highly effective siRNA sequences for mammalian and chick RNA interference. Nucleic Acids Res 32: 936-948, 2004.

18. Albertin G, Carraro G, Petrelli L, Guidolin D, Neri G and Nussdorfer GG: Endothelin-1 and adrenomedullin enhance the growth of human adrenocortical carcinoma-derived SW-13 cell line by stimulating proliferation and inhibiting apoptosis. Int J Mol Med 15: 469-474, 2005.

19. Albertin G, Carraro G and Nussdorfer GG: Human adrenomedullin gene silencing by short interfering RNAs: A preliminary study. Int J Mol Med 15: 579-583, 2005.
20. Albertin G, Rucinski M, Carraro G, Forneris M, Andreis $P$, Malendowicz LK and Nussdorfer GG: Adrenomedullin and vascular endothelium growth factor genes are overexpressed in the regenerating rat adrenal cortex, and AM and VEGF reciprocally enhance their mRNA expression in cultured rat adrenocortical cells. Int J Mol Med 16: 431-435, 2005.

21. Carraro G, Albertin G, Aragona F, Forneris M, Casale V, Spinazzi R and Nussdorfer GG: Age-dependent decrease in the ghrelin gene expression in the human adrenal cortex: A realtime PCR study. Int J Mol Med 17: 319-321, 2006.

22. Spinazzi R, Petrelli L, Guidolin D, Carraro G, Casale V, Tortorella C, Neri G, Albertin G, Andreis PG and Nussdorfer GG: In vitro culture on Matrigel favors the long-term maintenance of rat zona glomerulosa-cell differentiated phenotype. Int J Mol Med 17: 1101-1110, 2006.

23. Pfaffl MW: A new mathematical model for relative quantification in real-time RT-PCR. Nucleic Acids Res 29: 2002-2007, 2001.

24. Baiguera S, Conconi MT, Guidolin D, Mazzocchi G, Malendowicz LK, Parnigotto PP, Spinazzi R and Nussdorfer GG: Ghrelin inhibits in vitro angiogenic activity of rat brain microvascular endothelial cells. Int J Mol Med 14: 849-854, 2004.

25. Conconi MT, Nico B, Guidolin D, Baiguera S, Spinazzi R, Rebuffat P, Malendowicz LK, Vacca A, Carraro G, Parnigotto PP, Nussdorfer GG and Ribatti D: Ghrelin inhibits FGF-2-mediated angiogenesis in vitro and in vivo. Peptides 25: 2179-2185, 2004.

26. Guidolin D, Vacca A, Nussdorfer GG and Ribatti D: A new image analysis method based on topological and fractal parameters to evaluate the angiostatic activity of docetaxel by using the Matrigel assay in vitro. Microvasc Res 67: 117-124, 2004.

27. Mittal V: Improving the efficiency of RNA interference in mammals. Nat Rev Genet 5: 117-124, 2004

28. Hall J: Unravelling the general properties of siRNAs: strength in numbers and lessons from the past. Nat Rev Genet 5: 552-557, 2004.

29. Sledz CA, Holko M, De Veer MJ, Silverman RH and Williams BR: Activation of the interferon system by RNAi vectors in mammalian cells. Nat Cell Biol 5: 834-839, 2003.

30. Tomoda Y, Izumi Y, Katafuchi T and Minamino N: Regulation of adrenomedullin secretion from cultured cells. Peptides 22: 1783-1794, 2001.

31. Hofbauer KH, Schoof E, Kurtz A and Sandner P: Inflammatory cytokines stimulate adrenomedullin expression through nitric oxide-dependent and -independent pathways. Hypertension 39: 161-167, 2002.

32. Tanaka T, Akiyama H, Kanai H, Sato M, Takeda S, Sekiguchi K, Yokoyama T and Kurabayashi M: Endothelial PAS domain protein 1 (EPAS 1) induces adrenomedullin gene expression in cardiac myocytes. J Mol Cell Cardiol 34: 739-748, 2002

33. Eto T, Kato J and Kitamura K: Regulation of production and secretion of adrenomedullin in the cardiovascular system. Regul Pept 112: 61-69, 2003.

34. Takahashi K, Udono-Fujimori R, Totsune K, Murakami O and Shibahara S: Suppression of cytokine-induced expression of adrenomedullin and endothelin-1 by dexamethasone in T98G human glioblastoma cells. Peptides 24: 1053-1062, 2003.

35. Ribatti D, Nico B, Spinazzi R, Vacca A and Nussdorfer GG: The role of adrenomedullin in angiogenesis. Peptides 26: 1670-1675, 2005

36. Ribatti D, Guidolin D, Conconi MT, Nico B, Baiguera S, Parnigotto PP, Vacca A and Nussdorfer GG. Vinblastine inhibits the angiogenic response induced by adrenomedullin in vitro and in vivo. Oncogene 22: 6458-6461, 2003. 